\title{
Isolation and characterization of secondary metabolites from apolar fraction of Scabiosa sicula and evaluation of their antioxidant activities
}

\author{
Scabiosa sicula'nin apolar fraksiyonundan ikincil metabolitlerin izolasyonu ve \\ karakterizasyonu ve antioksidant aktivitelerinin değerlendirilmesi
}

\author{
Hilal KILINÇ*1,a \\ ${ }^{1}$ Geological Engineering Department, Faculty of Engineering, Dokuz Eylül University, İzmir, Turkey
}

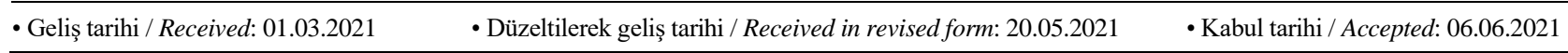

\begin{abstract}
In this study, the identification and characterization of Scabiosa sicula dichloromethane extract constituents were discussed for the first time. Moreover, this study is also providing an overview of the phytochemistry of Mediterranean medicinal plants. The phytochemical investigation of S. sicula dichloromethane extract was performed by HPLC and resulted in isolation of six compounds and five of them were identified as phenolic compounds and one as triterpene. The structures of the isolated compounds determined as luteolin-6-C-glucoside, luteolin-7-O-glucoside, caffeic acid, ursolic acid, 4-O-caffeoylquinic acid and 3,5-O-dicaffeoylquinic acid using spectroscopic analysis, including NMR and HR-MS techniques. Moreover, TEAC and DPPH assays were performed to evaluate the antioxidant activity of $S$. sicula's dichloromethane extract. TEAC value was defined as the concentration of Trolox solution with the same amount of antioxidant potential found in the $1 \mathrm{mg} / \mathrm{mL}$ solution of the tested extract resulted to be $1.21 \pm 0.01 \mathrm{mg} / \mathrm{mL}$. DPPH activity was calculated as $(4.42 \mu \mathrm{g} / \mathrm{mL})$ while the corresponding methanol extract antiradical activity was $3.34 \pm 0.01 \mu \mathrm{g} / \mathrm{mL}$. The contribution to literature with this study is to increase the depth of knowledge about $S$. sicula on secondary metabolites isolated from apolar fraction and the results of this study will help reveal the medical potential of these species.
\end{abstract}

Keywords: Caprifoliaceae, Scabiosa sicula, Secondary metabolites

$\ddot{\boldsymbol{O}_{z}}$

Bu çalışmada, Scabiosa sicula türünün diklorometan ekstresi bileşenlerinin tanımlanması ve karakterizasyonu ilk kez tartışılmıştır. Ayrıca, bu çalışma Akdeniz şifalı bitkilerinin fitokimyası hakkında genel bir bakış sunmaktadır. S. sicula diklorometan ekstresinin fitokimyasal incelenmesi HPLC ile yapılmış ve izole edilen altı bileşikten beş tanesinin fenolik bir tanesininde triterpen yapısında olduğu NMR ve HR-MS teknikleri kullanılarak luteolin-6-C-glukozit, luteolin-7-Oglukozit, kafeik asit, ursolik asit, 4-O-kafeoilkinik asit ve 3,5-O-dikaffeoilkinik asit olarak belirlenmiştir. S. sicula'nın diklorometan ekstresinin antioksidant aktivitesi TEAC ve DPPH yöntemleri ile incelenmiştir. TEAC değeri, test edilen ekstraktın $1 \mathrm{mg} / \mathrm{mL}$ solüsyonunda bulunan aynı miktarda antioksidan potansiyeline sahip Trolox solüsyonunun konsantrasyonuna bağlı olarak $1.21 \pm 0.01 \mathrm{mg} / \mathrm{mL}$ tanımland. DPPH aktivitesi $(4.42 \mu \mathrm{g} / \mathrm{mL}$ ) olarak hesaplanırken ona karşılık gelen metanol ekstresinin antiradikal aktivitesi $3.34 \pm 0.01 \mu \mathrm{g} / \mathrm{mL}$ olarak ölçülmüştür. Scabiosa sicula diklorometan ekstresinin ikincil metabolitlerinin tanımlandığı bu çalışmanın literatüre sağladığı katkl, bu türün tıbbi potansiyelinin ortaya çıkarılmasına yardım edecektir.

Anahtar kelimeler: Caprifoliaceae, Scabiosa sicula, İkincil metabolitler

\footnotetext{
${ }^{{ }^{*} a}$ Hilal KILINÇ; hilal.altunkeyik@deu.edu.tr, Tel:0232 3017340, orcid.org/0000-0003-3772-2691
} 


\section{Introduction}

People from past to present lived a life dependent on plants, one of the natural product sources. Especially, plants have played essential roles in the traditional medicine such as Scabiosa atropurpurea aerial parts are used as for measles infusion and diuretic (Bonet and Valles, 2007). Scabiosae flos are used to clearing blood heat in liver and against gastric disorder, S. succisa are used for the treatment of asthma, bronchitis and influenza (Corradi et al., 2016; Pinto et al., 2018, Zhang et al., 2015). S. columbaria is used as a medicine to treat diphtheria (Rigat et al., 2007) In additionally, some of Scabiosa species are used to skin diseases in Europe (Zheng et al., 2004). Scabiosa species are known to exhibit antioxidant, anti-acetylcholinesterase, antibacterial and antimicrobial activities. (Elhawaray et al., 2011; Hlila et al., 2015; Kose et al., 2015). This genus species has mainly revealed the presence of saponins, flavonoids and iridoids (Besbes et al., 2012; Pinto et al., 2018). Scabiosa sicula L., a genus of the Caprifoliaceae family is represented by 80 annual species distributed throughout the world, 30 species are endemic of Turkey (Panayır and Baykal, 1997; Reveal and Chase, 2011; Besbes et al., 2012). Scabiosa sicula L., Mant., which has a synonym name as Scabiosa lyrata, and is widely distributed in Mediterranean Basin, especially Antalya, Burdur, Çanakkale, Denizli, İzmir, Kocaeli, Konya, Siirt, Sivas and Uşak in Turkey (Davis, 1970). In addition, they are medicinal plants and they have been used as pharmaceutical, food and cosmetic industry. As a result of studies on this genus, new metabolites were isolated and some of them have shown a promising therapeutic agent (Wang et al., 2013; Pinto et al., 2018). Literature data showed that there is no phytochemical report about the $S$. sicula dichloromethane extract. In this content, this study aims to raise the depth of information about $S$. sicula apolar fraction. Additionally, Trolox Equivalent Antioxidant Capacity (6-hydroxy2,5,7,8-tetramethylchroman-2-carboxylic acid) and radical scavenging activity assays were carried out to determine the antioxidant activity of S. sicula apolar extract.

\section{Materials and methods}

\subsection{General}

All experiments were carried out using a Thermo scientific liquid chromatography system constituted of a quaternary Accela 600 pump and an Accela autosampler, connected to a linear Trap-
Orbitap hybrid mass spectrometer (LTQ-Orbitrap XL, Thermo Fisher Scientific, Bremen, Germany) with electrospray ionization (ESI). Separation was performed on a Kinetex EVO C18 $5 \mu \mathrm{m}$ $(150 \times 2.10 \mathrm{~mm}) \quad$ column (Phenomenex Aschaffenburg, Germany). The mobile phase consisted of solvent $\mathrm{A}\left(\mathrm{H}_{2} \mathrm{O}+0.1 \%\right.$ formic acid $)$ and solvent $\mathrm{B}\left(\mathrm{CH}_{3} \mathrm{CN}+0.1 \%\right.$ formic acid $)$. A linear gradient program at a flow rate of 0.200 $\mathrm{mL} / \mathrm{min}$ was used: $0-35 \mathrm{~min}$, from 5 to $95 \%$ (B); then 5\% (B) for $5 \mathrm{~min}$. The mass spectrometer operated in negative ion mode. ESI source parameters were as follows: capillary voltage -48 $\mathrm{V}$; tube lens voltage -176.47 ; capillary temperature $280{ }^{\circ} \mathrm{C}$; Sheath and Auxiliary Gas flow (N2), 15 and 5, respectively, Sweep gas 0 Spray voltage 5. MS spectra were acquired by full range acquisition covering $m / z 250-1600$ at a resolution of 30000. For fragmentation study, a data dependent scan was performed, selecting precursor ions corresponding to most intensive peaks in LCMS analysis with a normalization collision energy at $35 \%$. Xcalibur software version 2.1 was used for instrument control, data acquisition and data analysis. The molecular formulae were assigned with an accuracy inferior to $0.5 \mathrm{ppm}$ for all the compounds.

Waters Sep-Pak silica cartridges Vac 20cc (5g) and WATERS HPLC system were used for separations. HPLC separations were carried out on a WATERS system equipped with a R-401 A refractive index detector, a Symmetry Prep TM-C18 $(78 \times 300 \mathrm{~mm}$, $7 \mu \mathrm{m})$. Silica column seperations were performed Waters Sep-Pak cartridges Vac 20cc (5g) silica cartridge for solid phase extraction (made in Ireland).

Separation was performed on a Symmetry Prep TM-C18 column $(78 \times 300 \mathrm{~mm}, 7 \mu \mathrm{m})$ with $\mathrm{MeOH}-$ $\mathrm{H}_{2} \mathrm{O}$ (43:57), $\mathrm{MeOH}-\mathrm{H}_{2} \mathrm{O}$ (50:50) and $\mathrm{MeOH}-\mathrm{H}_{2} \mathrm{O}$ (55:45). TLC was performed on silica gel $\mathrm{F}_{254}$ Solvents used in this work, chloroform, methanol and water were purchased from Merck, Germany. TLC plates were developed by spraying cerium (IV) sulphate $\left(100^{\circ} \mathrm{C}\right.$ for $\left.6 \mathrm{~min}\right)$.

NMR experiments were recorded in methanol- $\mathrm{d}_{4}$ (99.95\%, Sigma-Aldrich) on a Bruker DRX-600 spectrometer (Bruker BioSpin GmBH, Rheinstetten, Germany) equipped with a Bruker 5 $\mathrm{mm}$ TCI CryoProbe at $300 \mathrm{~K}$. Topspin software 3.2 version was used for data analysis.

\subsection{Plant material}

Scabiosa sicula L. was collected May 2016, in Ulucak, Kemalpaşa, İzmir, Turkey (GPS coordinates latitude: 40.6355 , longitude: 14.8537). 
A voucher herbarium specimen has been deposited at the herbarium, Botanical Garden of Ege University, Izmir, Turkey (EGE-HERB 5481). Erect branched annual with pubescent stems 10-30 $\mathrm{cm}$ tall. Lower leaves oblong, dentate to lyrate; upper leaves pinnatisect with linear segments. Hills, open woodland, 200-1350 m (Davis, 1970).

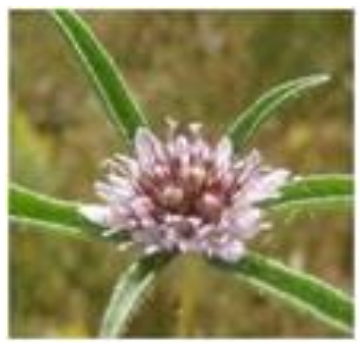

Figure 1. Picture of Scabiosa sicula

\subsection{Extraction and isolation}

S. sicula (455 g, whole plant) was dried under shade at room temperature for two weeks and finely ground. It was reduced to coarse powder and the powdered sample extracted at room temperature using solvents of $\mathrm{MeOH}(2 \times 2.5 \mathrm{~L}$ during three days/each day six hours). The remaining methanol after extraction was evaporated by rotavapor and the extract was dried. The light- brown residue (40.91 g) was dissolved in water and then partitioned successively with $n$ hexane $(2 \times 150 \mathrm{~mL})$ and dichloromethane $(2 \times 150$ $\mathrm{mL}$ ). All extracts were maintained $4{ }^{\circ} \mathrm{C}$ before further processes. Dichloromethane extract $(2.475$ g) was analyzed by separation method using SepPak C18 silica gel column. Some quantity of sample (250 mg to $2.5 \mathrm{~mL}$ ) was injected into a SepPak silica cartridges Vac 20cc (5g) column which prior to its use had been activated using ethyl acetate then methanol. It was eluted with $350 \mathrm{~mL}$ the mixture of chloroform: methanol (55:45) and collected, affording 42 fractions $(8 \mathrm{~mL})$. The purified fractions as monitored by TLC and then combined to their similarity.

Purification of fractions 3-19 (46 mg) by HPLC were performed on a Symmetry Prep TM-C18 column $(78 \times 300 \mathrm{~mm}, 7 \mu \mathrm{m})$ with $\mathrm{MeOH}-\mathrm{H}_{2} \mathrm{O}$ (43:57), at $2.4 \mathrm{~mL} / \mathrm{min}$ to give compounds 1 (4.2 $\left.\mathrm{mg}, t_{\mathrm{R}}=11.8 \mathrm{~min}\right)$ and $2\left(7.4 \mathrm{mg}, t_{\mathrm{R}}=12.7 \mathrm{~min}\right)$. Purification of fractions 20-29 (24 mg) by HPLC were performed on a Symmetry Prep TM-C18 column $(78 \times 300 \mathrm{~mm}, 7 \mu \mathrm{m})$ with $\mathrm{MeOH}-\mathrm{H}_{2} \mathrm{O}$ (50:50), at $2.4 \mathrm{~mL} / \mathrm{min}$ to yield compound 3 (3.2 $\left.\mathrm{mg}, t_{\mathrm{R}}=8.4 \mathrm{~min}\right)$. Purification of fractions $30-42$ (36 mg) by HPLC were performed on a Symmetry Prep TM-C18 column $(78 \times 300 \mathrm{~mm}, 7 \mu \mathrm{m})$ with
$\mathrm{MeOH}-\mathrm{H}_{2} \mathrm{O}(55: 45)$, at $2.4 \mathrm{~mL} / \mathrm{min}$ to give compounds 4 (2.6 mg, $\left.t_{\mathrm{R}}=5.4 \mathrm{~min}\right), \mathbf{5}\left(6.3 \mathrm{mg}, t_{\mathrm{R}}\right.$ $=9.8 \mathrm{~min})$ and $\mathbf{6}\left(4.7 \mathrm{mg}, t_{\mathrm{R}}=11.3 \mathrm{~min}\right)$.

\subsection{Antioxidant activity (TEAC) assay}

The antioxidant capacity of the apolar extract was measured according to Santos et al. (2017). Briefly, extract was prepared in diluted methanol solutions at four different concentrations range between 250 to $1000 \mu \mathrm{g} / \mathrm{mL}$. The process was started by adding $1.5 \mathrm{~mL}$ of diluted ABTS to $15 \mu \mathrm{L}$ of each sample. The reduction in the absorbance percentage at 734 $\mathrm{nm}$ was calculated for each concentration relative to methanol (blank absorbance). Trolox was used as a positive control and the antioxidant activity was presented as $\mathrm{mg}$ of quercetin equivalents per $\mathrm{mL}$ extract $(\mathrm{mg} / \mathrm{mL})$. All the experiments were repeated three times.

\subsection{1,1-Diphenyl-2-picrylhydrazyl (DPPH*) Radical scavenging activity}

$\mathrm{DPPH}^{\circ}$ activity was performed by spectrophotometric method based on the reduction of DPPH according to the Cerulli et al. (2017). In this method, DPPH solution $(1.5 \mathrm{~mL}, 0.025 \mathrm{~g} / \mathrm{L}$ in $\mathrm{MeOH}$ ) and methanol solution containing different amounts of extract $(37.5 \mu \mathrm{L})$ were added to each well of tubes and mixed. Vitamin $\mathrm{C}$ was used as positive control and this activity was expressed against to $\mathrm{DPPH}^{\cdot}$ (an equal volume). The samples were kept in the dark $\left(25^{\circ} \mathrm{C}\right)$. After 10 minutes, the absorbances of samples were read at $517 \mathrm{~nm}$ wavelength. Experiments were carried out in triplicate. The calculation of activity was performed our previous study (Kılınç et al., 2020).

\section{Results and discussion}

\subsection{Phytochemical results}

Indeed, several phytochemical studies carried out on Scabiosa species are examined, secondary metabolites have been found that this genus species is rich in flavonoids and terpenoids. The flavonoids were isolated previously from many Scabiosa species such as $S$. ochroleuca and S. bipinnata (Zemtsova et al., 1968), S. caucasica (Garaev et al., 2008), S. tenuis and S. argentea (Perdetzoglou et al., 1994). Triterpenoids have been found in the species S. tschiliensis (Zheng et al., 2004), S. rotata (Baykal et al., 1998) and S. stellata (Lehbili et al., 2018). By detailed phytochemical analysis, the chemical constituents of $S$. sicula apolar fraction were investigated for the first time. As a result of phytochemical study, six compounds were isolated 
from the apolar fraction of S. sicula, and five of them were identified as phenolic compounds (1$\mathbf{3 , 5 , 6 )}$ and one as triterpene derivative (4). The structures of the isolated compounds determined as luteolin-6- $C$-glucoside (1), luteolin-7- $O$-glucoside (2), caffeic acid (3), ursolic acid (4), 4-Ocaffeoylquinic acid (5) and 3,5-O-dicaffeoylquinic acid (6) by using ${ }^{1} \mathrm{H}-\mathrm{NMR}, 2 \mathrm{D}-\mathrm{NMR}$ and HR-MS spectral analyses, and also by comparison with literature surveys (Figure 2).
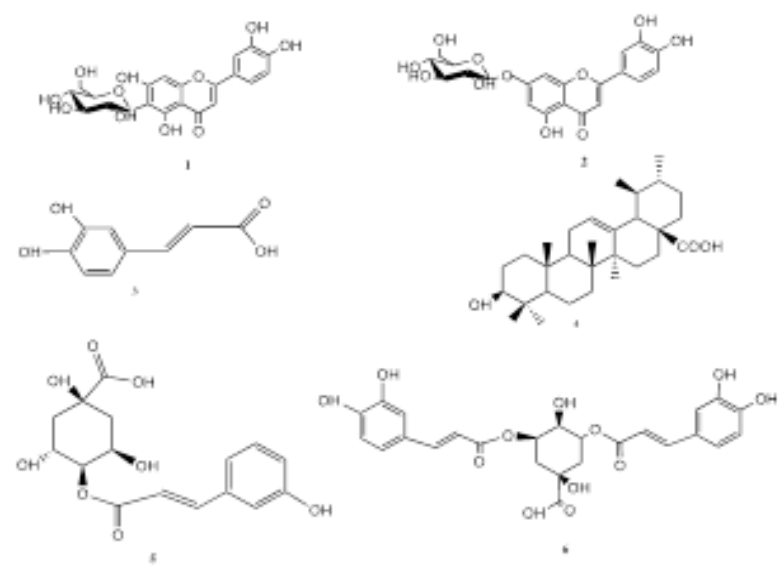

Figure 2. Structure of Isolated Compounds

Luteolin-6- $\boldsymbol{C}$-glucoside (1): The molecular mass of compound 1 was calculated as $m / z 447.0935$ according to its molecular formula $\mathrm{C}_{21} \mathrm{H}_{20} \mathrm{O}_{11}$ and found $\mathrm{m} / \mathrm{z} 447.3333$ by HR-MS in negative ion mode $[\mathrm{M}-\mathrm{H}]^{-}$(Figure 3). ${ }^{1} \mathrm{H}$ NMR (methanol- $d_{4}$, $600 \mathrm{MHz}) \delta 4.58\left(1 \mathrm{H}, \mathrm{d}, J=9.5 \mathrm{~Hz}, \mathrm{H}-1^{\prime \prime}\right), 6.64$ $(1 \mathrm{H}, \mathrm{s}, \mathrm{H}-3), 6.44(1 \mathrm{H}, \mathrm{s}, \mathrm{H}-8), 6.86(1 \mathrm{H}, \mathrm{d}, J=8.8$ $\left.\mathrm{Hz}, \mathrm{H}-5^{\prime}\right), 7.38\left(1 \mathrm{H}, \mathrm{d}, J=1.9 \mathrm{~Hz}, \mathrm{H}-2^{\prime}\right), 7.41(1 \mathrm{H}$, $\mathrm{dd}, J=1.9 \mathrm{~Hz}, 8.2 \mathrm{~Hz}, \mathrm{H}-6^{\prime}$ ); (Figure 4).

The phenolic compound was herein reported, it was determined for the first time ethanolic extract profile of S. stellata. To confirm the definition it is characterization was carefully and compared Rahmouni et al. (2018a) with the previous report data and accordingly the compound was identified as luteolin-6- $C$-glucoside (isoorientin).

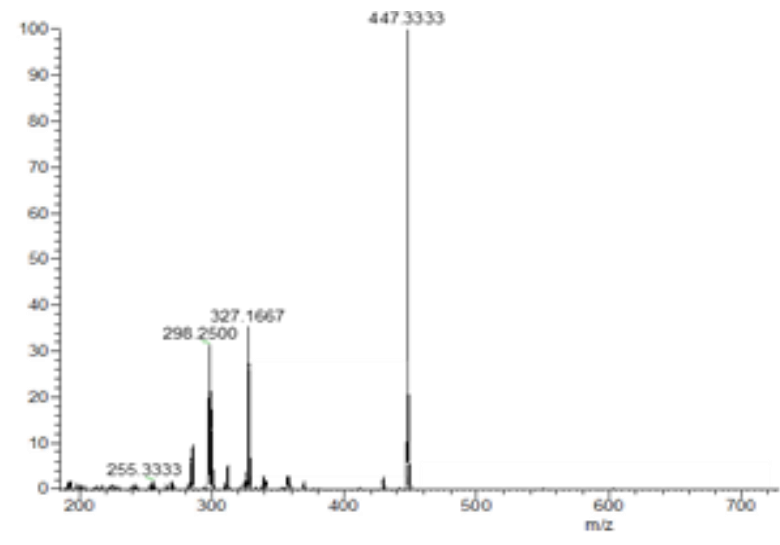

Figure 3. HRMS Spectrum of compound 1

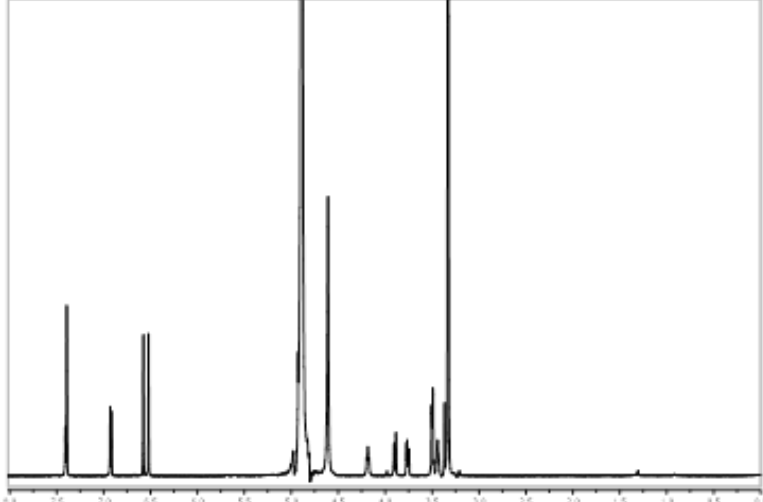

Figure 4. ${ }^{1} \mathrm{H}$ NMR Spectrum of compound 1

Luteolin-7-O-glucoside (2): The molecular mass of compound 2 was calculated as $\mathrm{m} / z 447.0935$ according to its molecular formula $\mathrm{C}_{21} \mathrm{H}_{20} \mathrm{O}_{11}$. and found $\mathrm{m} / z 447.0919$ by HR-MS in negative ion mode $[\mathrm{M}-\mathrm{H}]^{-}$(Figure 5). The MS/MS spectrum of compound $2[\mathrm{M}-\mathrm{H}]^{-}$ion at $\mathrm{m} / \mathrm{z} 285.04$ was produced by the neutral loss $162 \mathrm{Da}$, corresponding to one hexose unit. ${ }^{1} \mathrm{H}$ NMR (methanol- $d_{4}, 600$ MHz) $\delta 5.07\left(1 \mathrm{H}, \mathrm{d}, J=8 \mathrm{~Hz}, \mathrm{H}-1^{\prime \prime}\right), 6.50(1 \mathrm{H}, \mathrm{d}$, $J=2.1 \mathrm{~Hz}, \mathrm{H}-6), 6.61(1 \mathrm{H}, \mathrm{s}, \mathrm{H}-3), 6.80(1 \mathrm{H}, \mathrm{d}, J$ $=2.0 \mathrm{~Hz}, \mathrm{H}-8), 6.90\left(1 \mathrm{H}, \mathrm{d}, J=8.0 \mathrm{~Hz}, \mathrm{H}-5^{\prime}\right), 7.40$ $\left(1 \mathrm{H}, \mathrm{dd}, J=8.0,2.1 \mathrm{~Hz}, \mathrm{H}-2^{\prime}\right), 7.43(1 \mathrm{H}, \mathrm{dd}, J=$ 8.0, $2.1 \mathrm{~Hz}, \mathrm{H}-6$ '); (Figure 6). In the literature, Hlila et. al. (2015) demonstrated that the aerial part $\mathrm{BuOH}$ fraction of $S$. arenaria isolated of luteolin 7O-glucoside which are reported first time for $S$. arenaria. Moreover, luteolin 7-O-glucoside was isolated from $S$. atropurpurea L. (Elhawaray et al., 2011), S. caucasica (Garaev et al., 2008), S. ochroleuca L. and S. bipinnata (Zemtsova et al., 1968), S. tenuis and S. argentea L. (Perdetzoglohu et al., 1994).

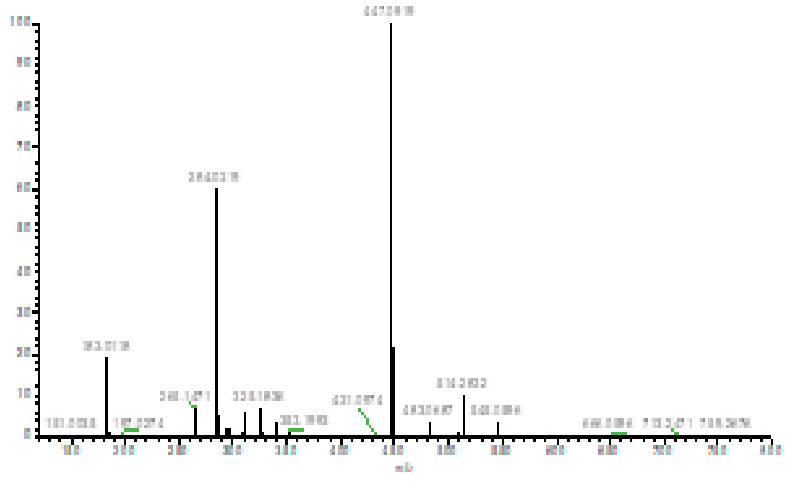

Figure 5. HRMS Spectrum of compound 2 


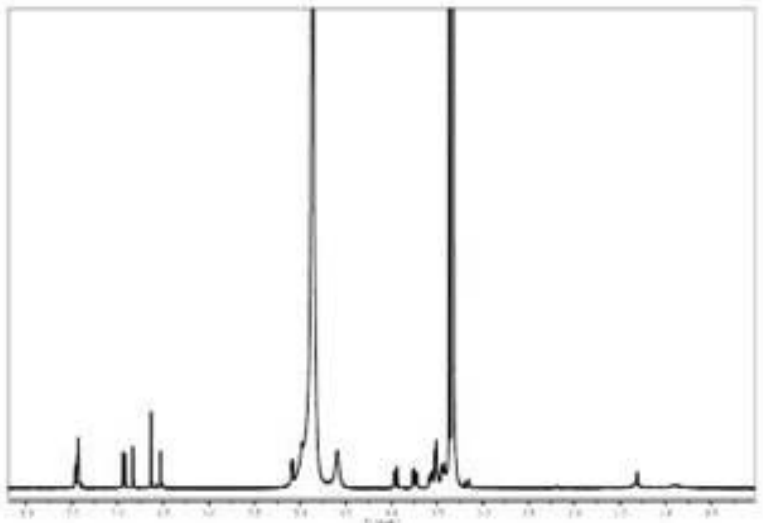

Figure 6. ${ }^{1} \mathrm{H}$ NMR Spectrum of compound 2

When the 1H- NMR and mass spectra of the two compounds are compared to the laboratory standard of luteolin 6-C-glucoside both compounds structure refer to the same molecule. Flavonoids in plants are mainly present as glycosides with a sugar moiety linked through an $\mathrm{OH}$ group (O-glycosides) or through carbon-carbon bonds (C-glycosides). Flavonoid glycosides have many isomers with the same molecular weight but different aglycone and sugar components are attached aglycone ring at different positions. The only difference between compound $\mathbf{1}$ and $\mathbf{2}$ is that the anomeric proton belonging to the glucose is bound to the aglycone from different carbon. The compound $\mathbf{1}$ anomeric proton signal was shifted at $\delta 4.58$ of the lowfield along with carbon at $\delta 73.4 \mathrm{ppm}\left(\mathrm{C}-1^{\prime \prime}\right)$.

Caffeic acid (3): The molecular mass of compound 3 was calculated as $m / z, 179.0346$ according to its molecular formula $\mathrm{C}_{9} \mathrm{H}_{8} \mathrm{O}_{4}$ and found $m / z, 179.0351$ by HR-MS in negative ion mode [M-H] (Figure 7). ${ }^{1} \mathrm{H}$ NMR (methanol- $\left.d_{4}, 600 \mathrm{MHz}\right) \delta 7.46(1 \mathrm{H}, \mathrm{d}, J$ $=16.1 \mathrm{~Hz}, \mathrm{H}-7), 7.01(1 \mathrm{H}, \mathrm{d}, J=1.7 \mathrm{~Hz}, \mathrm{H}-2), 6.91$ $(1 \mathrm{H}, \mathrm{dd}, J=1.9,8.2 \mathrm{~Hz}, \mathrm{H}-6), 6.74(1 \mathrm{H}, \mathrm{d}, J=8.15$ $\mathrm{Hz}, \mathrm{H}-5), 6.22$ (1 H, d, J = 15.8 Hz, H-8); (Figure 8). Caffeic acid structure compared with the literature data given in Jeong et al. (2011), it was identified as caffeic acid which was very common phenolic compound.

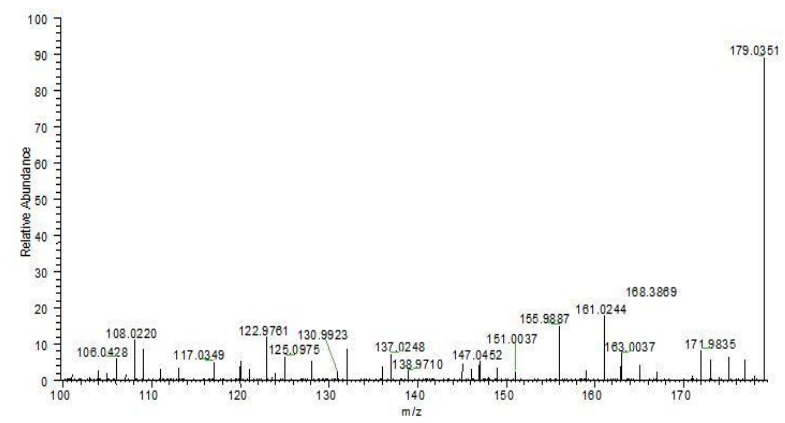

Figure 7. HRMS Spectrum of compound $\mathbf{3}$

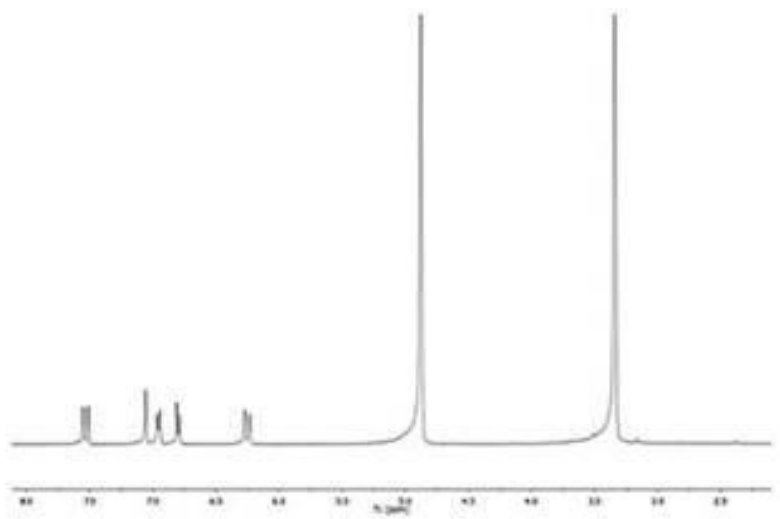

Figure 8. ${ }^{1} \mathrm{H}$ NMR Spectrum of compound 3

Ursolic acid (4): The molecular mass of compound 4 was calculated as $m / z 455.2741$ according to its molecular formula $\mathrm{C}_{30} \mathrm{H}_{48} \mathrm{O}_{3}$ and found $\mathrm{m} / \mathrm{z}$ 455.3497 by HR-MS in negative ion mode [M-H] (Figure 9). ${ }^{1} \mathrm{H}$ NMR (methanol- $\left.d_{4}, 600 \mathrm{MHz}\right) \delta$ $0.68(1 \mathrm{H}, \mathrm{d}, \mathrm{H}-5), 0.73$ (3H, s, H-25), 0.76 (s, H24), $0.82(3 \mathrm{H}, \mathrm{d}, \mathrm{H}-30), 0.87$ (3H, s, H-26), 0.90 (3H, d, H-29), 0.93 (3H, m, H-23), 0.98 (1H, m, H20), 1.04 (3H, s, H-27), 2.18 (1H, d, H-18), 3.18 $(1 \mathrm{H}, \mathrm{t}, J=16.4 \mathrm{~Hz}, \mathrm{H}-3), 5.21(1 \mathrm{H}, \mathrm{s}, \mathrm{H}-12)$; (Figure 10). According to the NMR data of compound 4 showed signals for seven methyl groups at $\delta 0.73,0.76,0.82,0.87,0.90,0.93$ and 1.04 ppm correspond H-25, H-24, H-30, H-26, H$29, \mathrm{H}-23$ and $\mathrm{H}-27$ respectively. The signal at $\delta$ 2.18 was attributed to $\mathrm{H}-18$ while $\mathrm{H}-3$ signal was observed at $\delta 3.18$. The hydroxymethyl group $(\mathrm{H}-$ $3)$ at $\delta 3.18 \mathrm{ppm}$ corresponds to the carbon signal at $\delta 78.6(\mathrm{C}-3)$ and carbonyl group (C-28) at $\delta$ $180.6 \mathrm{ppm}$. Correlations of $\mathrm{H}-12$ at $\delta 5.21 \mathrm{ppm}$ with $\mathrm{C}-12$ at $\delta 125.1$ and at $\delta 5.21 \mathrm{ppm}$ were observed as a large triplet attributed to $\mathrm{H}-12$ made the location of olefinic methyl groups. When the previous studies are examined, ursolic acid was first isolated from Scabiosa stellata hexane extract (Rahmouni et al., 2018b). Based on the referred data and by comparison with the reported literature (Gnoatto et al., 2008), the structure of compound 4 was confirmed to be $3 \beta$-hydroxyurs-12-en-28-oic acid or ursolic acid.

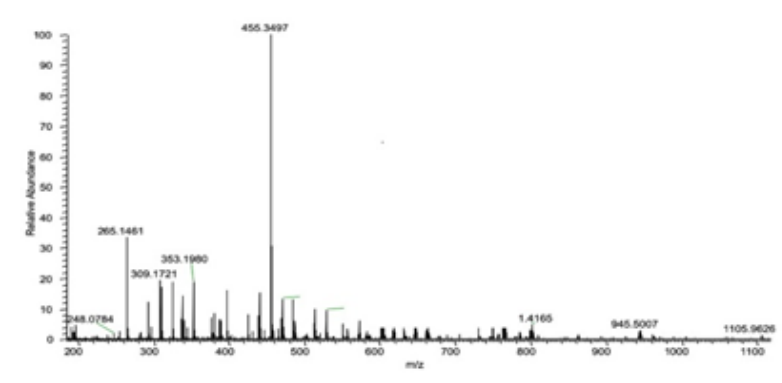

Figure 9. HRMS Spectrum of compound 4 


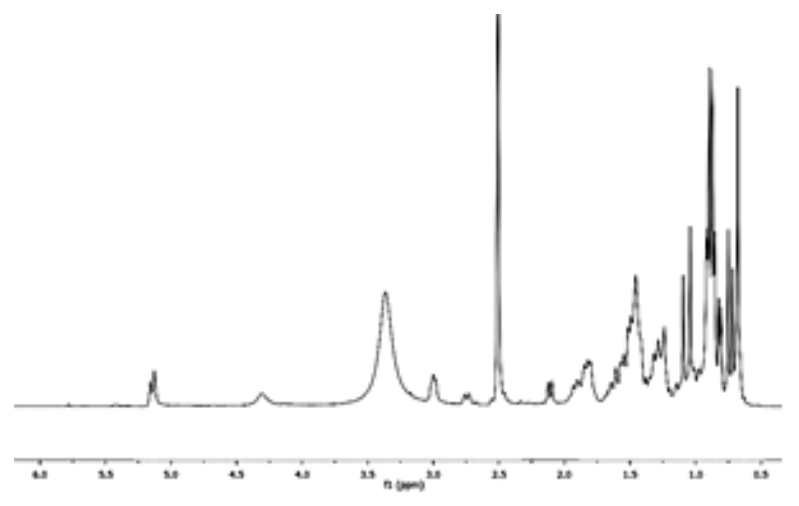

Figure 10. ${ }^{1} \mathrm{H}$ NMR Spectrum of compound 4

4- $\boldsymbol{O}$-caffeoylquinic acid (5): The molecular mass of compound $\mathbf{5}$ was calculated as $\mathrm{m} / \mathrm{z} 353.0880$ according to its molecular formula $\mathrm{C}_{16} \mathrm{H}_{18} \mathrm{O}_{9}$ and found $\mathrm{m} / \mathrm{z} 353.2347$ by HR-MS in negative ion mode $[\mathrm{M}-\mathrm{H}]^{-}$(Figure 11). ${ }^{1} \mathrm{H}$ NMR (methanol- $d_{4}$, $600 \mathrm{MHz}) \delta 7.63\left(1 \mathrm{H}, \mathrm{d}, J=15.9 \mathrm{~Hz}, \mathrm{H}-7^{\prime}\right), 6.37$ $\left(1 \mathrm{H}, \mathrm{d}, J=15.9 \mathrm{~Hz}, \mathrm{H}-8^{\prime}\right), 7.06\left(1 \mathrm{H}, \mathrm{H}-2^{\prime}\right), 6.97$ $\left(1 \mathrm{H}, \mathrm{H}-6^{\prime}\right), 6.78\left(1 \mathrm{H}, \mathrm{H}-5^{\prime}\right)$ and quinic acid signals at $\delta 4.29(1 \mathrm{H}$, brs, $\mathrm{H}-3), 4.80(1 \mathrm{H}, \mathrm{dd}, J=9.0 \mathrm{~Hz}$, $2.3 \mathrm{~Hz}, \mathrm{H}-4), 4.27$ (1H, ddd, $J=9.0 \mathrm{~Hz}, 9.0 \mathrm{~Hz} 4.5$ $\mathrm{Hz}, \mathrm{H}-5$ ), 1.98-2.23 (4H, m, H-2,6); (Figure 12). The ${ }^{13} \mathrm{C}$ NMR spectrum for the $4-O$-caffeoylquinic acid presents 16 carbon atoms, with 7 carbons for the quinic and 9 carbons for caffeoyl moieties. The shift of $\mathrm{H}-4$ signal of quinic acid from $\delta 4.60 \mathrm{ppm}$ to $4.80 \mathrm{ppm}$ and coupling constant of $\mathrm{H}-4$ (dd) at $9.0 \mathrm{~Hz}$ and $2.3 \mathrm{~Hz}$ were proved to substitution took place at position 4 of quinic acid compared with literature data. Besides chemical shift of H-4 signal, small coupling constant of $\mathrm{H}-3$ and coupling constants of $\mathrm{H}-5$ (ddd) at $9.0 \mathrm{~Hz}, 9.0 \mathrm{~Hz}$, and 4.5 $\mathrm{Hz}$ were also confirm the substitution at this position (Chuppeng et al., 2017).

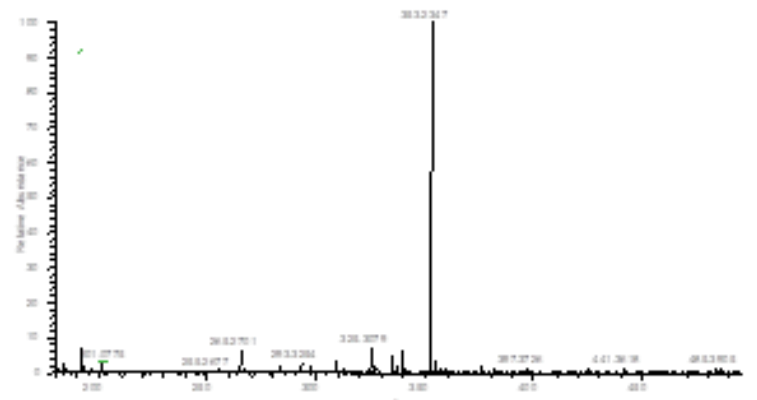

Figure 11. HRMS Spectrum of compound 5

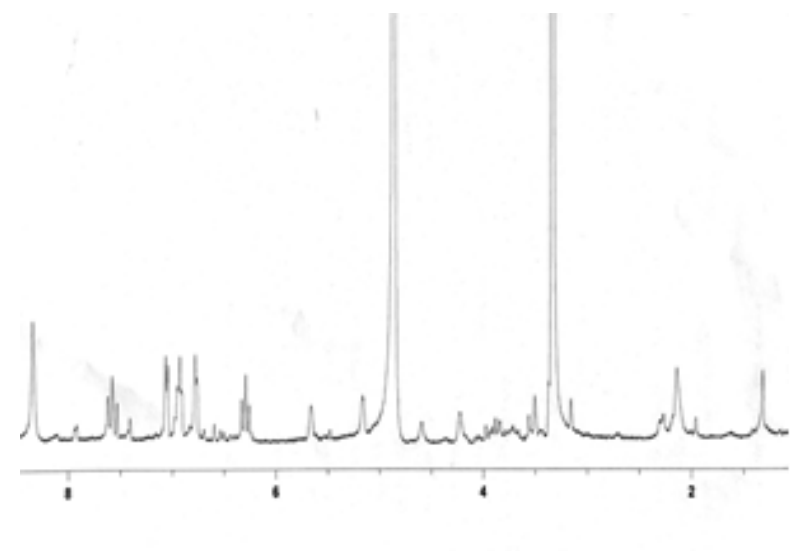

Figure 12. ${ }^{1} \mathrm{H}$ NMR Spectrum of compound 5

3,5-O-dicaffeoylquinic acid (6): The molecular mass of compound $\mathbf{6}$ was calculated as $\mathrm{m} / \mathrm{z}$ 515.1191 according to its molecular formula $\mathrm{C}_{25} \mathrm{H}_{24} \mathrm{O}_{12}$ and found $\mathrm{m} / z 515.1722$ by HR-MS in negative ion mode $[\mathrm{M}-\mathrm{H}]^{-}$(Figure 13). The ${ }^{1} \mathrm{H}$ $\mathrm{NMR}$ (methanol- $d_{4}, \quad 600 \mathrm{MHz}$ ) spectrum of compound 6 showed two sets of caffeoyl th7.07 $\left(1 \mathrm{H}, \mathrm{d}, J=2.4 \mathrm{~Hz}, \mathrm{H}-2^{\prime \prime}\right), 6.85(1 \mathrm{H}, \mathrm{dd}, J=8.3 \mathrm{~Hz}$, $\left.2.0 \mathrm{~Hz}, \mathrm{H}-6^{\prime}\right), 6.78\left(1 \mathrm{H}, \mathrm{d}, J=8.3, \mathrm{H}-5^{\prime \prime}\right), 6.97(1 \mathrm{H}$, $\left.\mathrm{dd}, J=8.3 \mathrm{~Hz}, 2.0 \mathrm{~Hz}, \mathrm{H}-6^{\prime \prime}\right), 6.78\left(1 \mathrm{H}, \mathrm{H}-5^{\prime}\right), 6.28$ $\left(1 \mathrm{H}, \mathrm{d}, \mathrm{J}=15.8 \mathrm{~Hz}, \mathrm{H}-8^{\prime}, 8^{\prime \prime}\right), 6.36(1 \mathrm{H}, \mathrm{d}, \mathrm{J}=15.8$ $\left.\mathrm{Hz}, \mathrm{H}-8^{\prime \prime}\right)$ and $5.42(2 \mathrm{H}, \mathrm{m}, \mathrm{H}-3,5), 3.97(1 \mathrm{H}, \mathrm{d}, J$ $=4.1 \mathrm{~Hz}, \mathrm{H}-4), 2.31(1 \mathrm{H}$, brs, H-6 $), 2.22(2 \mathrm{H}, \mathrm{m}$,

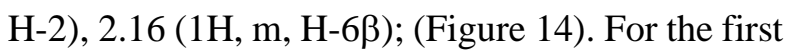
time, 3,5- $O$-dicaffeoylquinic acid (DCQA), was identified from genus Scabiosa (Ma et al., 2016).

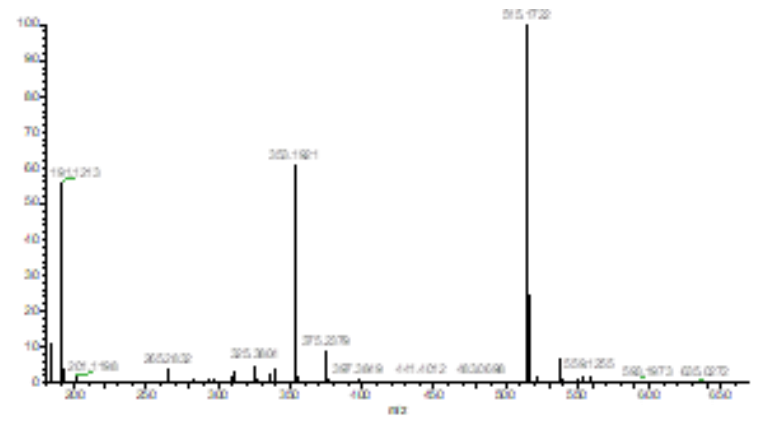

Figure 13. HRMS Spectrum of compound 6

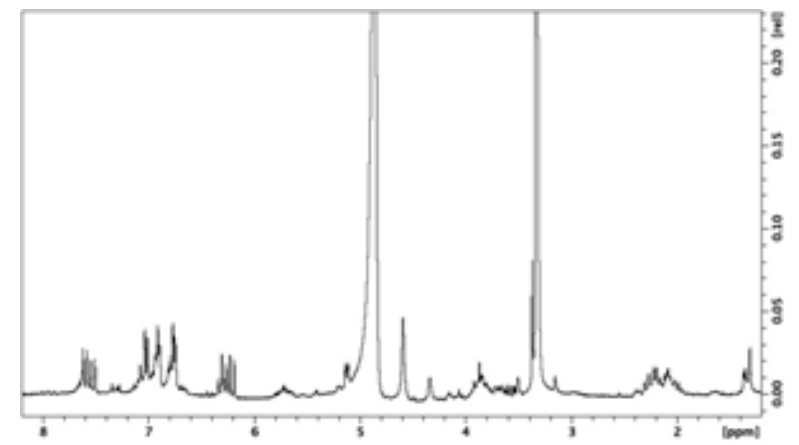

Figure 14. ${ }^{1} \mathrm{H}$ NMR Spectrum of compound 6 
In the structure of compound $\mathbf{6}$, different from compound $\mathbf{5}$, there are two trans-caffeoyl groups and one quinic acid. The acylation positions of both compounds were determined by using the chemical shift and coupling constants of the oxygenated methine protons of the quinic acid. The $\mathrm{H}-5$ signal of compound $\mathbf{5}$ was shifted to downfield and proved the acylation at this position for compound 6.

\subsection{Activity results}

The antioxidant properties of $S$. sicula dichloromethane extract was evaluated using different assays including TEAC and free radical scavenging (DPPH) tests. TEAC value was defined as the concentration of Trolox solution with the same amount of antioxidant potential found in the $1 \mathrm{mg} / \mathrm{mL}$ solution of the tested extract resulted to be $1.21 \pm 0.01 \mathrm{mg} / \mathrm{mL}$. The TEAC value of extract was compared to quercetin $0.663 \mathrm{mM}$ (do Amaral et al; 2012). The calculated $\mathrm{EC}_{50}$ value $\mu \mathrm{g} / \mathrm{mL}$ indicates the concentration required to scavenge $50 \%$ of DPPH of the free radical scavenging activity of the apolar extract expressed as $\mu \mathrm{g} / \mathrm{mL}$ of sample (Cerulli et al., 2018). In this analysis, vitamin $\mathrm{C}$ was used the reference and its antiradical activity was calculated as $(4.42 \mu \mathrm{g} / \mathrm{mL})$ while the corresponding methanol extract antiradical activity was $3.34 \pm 0.01 \mu \mathrm{g} / \mathrm{mL}$.

The antioxidant activity in secondary metabolite structures was found to depend on the number of active groups $(\mathrm{OH})$ involved in the structure. In addition, it has been determined that the presence of active groups in the structure of the compounds increases the antioxidant activity of the compounds. Depending on the location of active groups in the structure and which active group is involved in the structure, it plays an important role in the structure-antioxidant activity relationship (Bendary et al., 2013; Valgimigli et al., 2008).

All of the pure compounds isolated from dichloromethane extract were also isolated from the methanol extract of $S$. sicula (K1lınç et al., 2020). In this respect, it has been determined that the secondary metabolites content of the dichloromethane extract similar to some of the secondary metabolite content of the methanolic extract. When the comparison was done between our previous study and this study, S. sicula methanol extract is particularly rich in triterpene compounds and eight new triterpene saponin compounds have been presented in the literature as new compounds. The $\alpha$-glucosidase inhibitory activity of the methanol extract showed a high value supporting the rich triterpene saponin content of the extract. On the other hand, only one known triterpene structure was isolated from dichloromethane fraction and the other compounds were phenolic structures. Therefore, this feature approved the antioxidant activities due to rich phenolic compounds it contains. The most important point is in this study, the identification and characterization of Scabiosa sicula dichloromethane extract constituents were discussed for the first time.

\section{Conclusion}

There is no phytochemical investigation on $S$. sicula dichloromethane extract, so the present study was the first phytochemical research study on dichloromethane extract of this species. In summary, six compounds were isolated from $S$. sicula apolar fraction and their structures were determined by spectroscopic techniques comparing with literature. Five of isolated compounds (1-3, 5, 6) were characterized as phenolic compounds and previously isolated from $S$. comosa, $S$. tschilliensis, S. sicula and S. stellata (Ma et al., 2016, Rahmouni et al., 2018a, Kilınç et al., 2020) whereas compound $\mathbf{4}$ which is terpenoid was isolated from S. stellata and S. sicula (Rahmouni et al., 2018b, Kilınç et al., 2020). The results of this study show that secondary metabolites that make up $S$. sicula extract also contribute to the formation of a natural antioxidant source. With this study, it has been understood that some secondary metabolites that are used in traditional medicine are used properly and in addition to these usage areas, they can also be used in cosmetic, food supplement and new drug studies. It is also able to give an idea for further studies in the future. To summarize, $S$. sicula is a good source of new pharmaceutical products (Hlila et al., 2015).

\section{Acknowledgement}

The author would like to thank TUBITAK 2219 Grant number: 1059B191700874.

\section{References}

Baykal, T., Panayir, T., Tasdemir, D., Sticher, O. And Calis, I. (1998). Triterpene saponins from Scabiosa rotata. Phytochemistry, 48, 867-873. https://doi.org/10.1016/S0031-9422(97)00982-5

Bendary, E., Francis, R.R., Ali, H.M.G., Sarwat, M.I. and El Hady S. (2013). Antioxidant and structure-activity relationships (SARs) of some phenolic and anilines compounds. Annals of 
Agricultural Science, 58, 173- 181. https://doi.org/10.1016/j.aoas.2013.07.002

Besbes, M., Omri A., Cheraif, I., Daami, M., Jannet, H.B., Mastouri, M., Aouni, M. and Selmi, B. (2012). Chemical composition and antimicrobial activity of essential oils from Scabiosa arenaria Forssk. growing wild in Tunisia. Chemistry \& Biodiversity, $9, \quad 829-839$. https://doi.org/10.1002/cbdv.201100191

Bonet, M. and Valles, J. (2007). Ethnobotany of Montseny biosphere reserve (Catalonia, Iberian Peninsula): Plants used in veterinary medicine. Journal of Ethnopharmacology, 110, 130-147. https://doi.org/10.1016/j.jep.2006.09.016

Cerulli, A., Lauro, G., Masullo, M., Cantone, V., Olas, B., Kontek, B., Nazzaro, F., Bifulco, G. and Piacente, S. (2017). Cyclic diarylheptanoids from Corylus avellana green leafy covers: determination of their absolute configurations and evaluation of their antioxidant and antimicrobial activities. Journal of Natural Products, $\quad 80, \quad$ 1703-1713. https://doi.org/10.1021/acs.jnatprod.6b00703

Cerulli, A., Masullo, M., Montoro, P., Hosek, J., Pizza, C., Piacente, S. (2018). Metabolite profiling of "green" extracts of Corylus avellana leaves by ${ }^{1} \mathrm{H} \quad$ NMR spectroscopy and multivariate statistical analysis. Journal of Pharmaceutical and Biomedical Analysis; 160, 168-178. https://doi.org/10.1016/j.jpba.2018.07.046

Chuppeng, W., Shanshan, L., Lin, L., Chuying, C. and Shuying, F. (2017). Caffeoylquinic acids from the aerial parts of Chrysanthemum coronorium $\mathrm{L}$. Plants, 6, 10. https://doi.org/10.3390/plants6010010

Corradi, E., De Mieri, M., Gafner, F., Hamburger, M. and Potterat, O. (2016). A new secoiridoid glucoside and a metabolite profile of Scabiosa lucida. Natural Product Communications, 11, 887-890.

https://doi.org/10.1177/1934578X1601100705

Davis, P.H. (1970). Flora of Turkey: Edinburg, University Press.

Do A.F.P., Napolitano, A., Masullo, M., dos Santos, L.C., Festa, M., Vilegas, W., Pizza, C. and Piacente, S. (2012). HPLC-ESIMS ${ }^{\mathrm{n}}$ profiling, isolation, structural elucidation, and evaluation of the antioxidant potential of phenolics from Paepalanthus geniculatus. Journal of Natural Products, $\quad 75$, 547-556. https://doi.org/10.1021/np200604k

Elhawary, S.S., Eltantawy, M.E., Sleem, A.A., Abdallah, H.M. and Mohamed, N.M. (2011). Investigation of phenolic content and biological activities of Scabiosa atropurpurea L. World Applied Sciences Journal, 15, 311-317.

Garaev, E. A., Movsumov, I. S. and Isaev, M. I. (2008). Flavonoids and oleanolic acid from Scabiosa caucasica. Chemistry of Natural Compounds, 44, 4. https://doi.org/10.1007/s10600-008-9108-x

Gnoatto, S.C.B., Dassonville-Klimpt A., Da Nascimento, S., Gale' ra, P., Boumediene, K., Gosmann, G., Sonnet, P. and Moslemi S. (2008). Evaluation of ursolic acid isolated from Ilex paraguariensis and derivatives on aromatase inhibition. European Journal of Medicinal Chemistry, 43, 1865-1877. https://doi.org/10.1016/j.ejmech.2007.11.021

Hlila, M.B., Mosbah, H., Majouli, K., Msaada, K., Ben J.H., Aouni, M. and Selmi, B. (2015). AlphaGlucosidase inhibition by Tunisian Scabiosa arenaria Forssk. extracts. International Journal of Biological Macromolecules, 77, 383-389. https://doi.org/10.1016/j.ijbiomac.2015.03.035

Jeong C., Jeong H., Choi G., Kim D., Lee U. and Heo H. (2011). Neuroprotective and anti-oxidant effects of caffeic acid isolated from Erigeron annuus leaf. Chinese Medicine, 6, 25. https://doi.org/10.1186/1749-8546-6-25

Kilınc, H., Masullo, M., D’Urso, G., Karayildirim T., Alankus, O. and Piacente S. (2020). Phytochemical investigation of Scabiosa sicula guided by a preliminary HPLC-ESIMS ${ }^{\mathrm{n}}$ profiling. Phytochemistry, 174. https://doi.org/10.1016/j.phytochem.2020.11235 0

Lehbili, M., Magid, A.A., Kabouche, A., VoutquenneNazabadioko, L., Morjani, H., Harakat, D. And Kabouche, Z. (2018). Triterpenoid saponins from Scabiosa stellata collected in North-eastern Algeria. Phytochemistry ,150, 40-49. https://doi.org/10.1016/j.phytochem.2018.03.00 5

Kose, L.S., Moteetee, A. and Van Vuuren, S. (2015). Ethnobotanical survey of medicinal plants used in the Maseru district of Lesotho. Journal of Natural Products, 170, 184-200. https://doi.org/10.1016/j.jep.2015.04.047

Ma, J.N, Bolraa, S., Ji, M., He, Q.Q. and Ma, C.M. (2016). Quantification and antioxidant and anti$\mathrm{HCV}$ activities of the constituents from the inflorescences of Scabiosa comosa and $S$. tschilliensis. Natural Product Research, 30, 590594.

https://doi.org/10.1080/14786419.2015.1027701

Panayır, T. and Baykal, T. (1997). Morphological and anatomical studies on Scabiosa rotata bieb. (Dipsacaceae). Journal of Faculty of Pharmacy 
of Ankara University, 26(1), 22-35. https://doi.org/10.1501/Eczfak_0000000311

Perdetzoglohu, D., Kaltsa, S., Tzakou, O. and Harvala, C. (1994). Comparative phytochemical and morphological study of two species of the Scabiosa L. genus. Feddes Repertorium, 105, 157 165. https://doi.org/10.1002/fedr.19941050305

Pinto, D.C.G.A., Rahmouni, N., Beghidja, N. and Silva, A.M.S. (2018). Scabiosa Genus: A rich source of bioactive metabolites. Medicines, 5, 110. https://doi.org/10.3390/medicines5040110

Rahmouni, N., Pinto, D.C.G.A., Beghidja, N., Benayache, S. and Silva, A.M.S. (2018a). Scabiosa stellata $\mathrm{L}$. Phenolic content clarifies its antioxidant activity. Molecules; 23,6, 1285. https://doi.org/10.3390/molecules23061285

Rahmouni N., Pinto, D.C.G.A., Santos S.A.O., Beghidja, N. and Silva A.M.S. (2018b). Lipophilic composition of Scabiosa stellata L.: an underexploited plant from Batna (Algeria). Chemical Papers, 72, 753-762. https://doi.org/10.1007/s11696-017-0308-3

Reveal, J.L. and Chase, M.W. (2011). Apg III: bibliographical information and synonymy of magnoliidae. Phytotaxa, 19, 71-134. https://doi.org/10.11646/phytotaxa.19.1.4

Rigat, M., Bonet, M. A., Garcia, S., Garnatje, T. and Valles, J. (2007). Studies on pharmaceutical ethnobotany in the high river Ter valley (Pyrenees, Catalonia, Iberian Peninsula). Journal of Ethnopharmacology, 113, 267-277. https://doi.org/10.1016/j.jep.2007.06.004

Santos, C.C.D., Masullo, M., Cerulli, A., Mari, A., Estevam, C.D., Pizza, C. and Piacente, S. (2017).
Isolation of antioxidant phenolics from Schinopsis brasiliensis based on a pre- liminary LC-MS profiling. Phytochemistry, 140, 45-51. https://doi.org/10.1016/j.phytochem.2017.04.00 8

Valgimigli, L., Amorati, R., Fumo M.G., Dilabio, G.A., Pedulli, G.F., Ingold, K.U. and Pratt, D. (2008). The unusual reaction of semiquinone radicals with molecular oxygen. The Journal of Organic Chemistry, 73, 1830-1841. https://doi.org/10.1021/jo7024543

Wang, J., Liu, K., Xu, D., Wang, Q., Bi, K., Song, Y., Li, J. and Zhang, L. (2013). Rapid micropropagation system in vitro and antioxidant activity of Scabiosa tschiliensis Grunning. Plant Growth Regulation, 69, 305-310. https://doi.org/10.1007/s10725-012-9765-4

Zemtsova, G.N., Bandyukova, V.A. and Shinkarenko, A.L. (1968). Quercetin diglucoside from the yellow Scabiosa. Pharmaceutical Chemistry Journal, 2, 12,180-678. https://doi.org/10.1007/BF00763332

Zhang, L., Cui, Z.H., Mu, Y.X., Wei, K.H., Li, Z.H., Zhu, H., Yang, D.W., Wang, Y.L., Long, P., Zhang, C.H. and Li, M.H. (2015). Ethnopharmacological investigation and rapid authentication of Mongolian patent medicines Digeda. Chinese Herbal Medicine, 7, 223-237. https://doi.org/10.1016/S1674-6384(15)60044-2

Zheng, Q., Koike, K., Han, L.K., Okuda, H. and Nikaido, T. (2004). New biologically active triterpenoid saponins from Scabiosa tschiliensis. Journal of Natural Products, 67, 604-613. https://doi.org/10.1021/np0304722 